\title{
Erratum: Universal conventional and real- time PCR diagnosis tools for Sarcoptes scabiei
}

Samer Angelone-Alasaad ${ }^{1,2^{*}}$, AnnaRita Molinar Min ${ }^{1}$, Mario Pasquetti ${ }^{1}$, Abdulaziz N. Alagaili ${ }^{3}$, Stefano D'Amelio ${ }^{4}$, Federica Berrilli ${ }^{5}$, Vincent Obanda ${ }^{6}$, Mohamed A. Gebely$^{7}$, Ramón C. Soriguer ${ }^{8}$ and Luca Rossi ${ }^{*}$

\section{Erratum}

After the publication of this work [1], we noticed an error in the Methods Section. The reported sequence of the ProSc " 5 '-GGTAACTTGTATGAAGGGACTAACTAAA$3^{\prime \prime}$ is not the correct one. The correct one is "ProSc: 5' GGTAACTTGTATGAAGGRAYTAACTAAA-3"”.

\begin{abstract}
Author details
'Dipartimento di Scienze Veterinarie, Largo Paolo Braccini 2, 10095 Grugliasco, Italy. ${ }^{2}$ Institute of Evolutionary Biology and Environmental Studies (IEU), University of Zürich, Winterthurerstrasse 190, 8057 Zürich, Switzerland. ${ }^{3}$ Department of Zoology, College of Science, King Saud University, Riyadh, Saudi Arabia. ${ }^{4}$ Department of Public Health and Infectious Diseases, University of Rome La Sapienza, Roma, Italy. ${ }^{5}$ Department of Experimental Medicine and Surgery, University of Rome Tor Vergata, Roma, Italy. ${ }^{6}$ Department of Veterinary Services, Kenya Wildlife Service, Nairobi, Kenya. ${ }^{7}$ Department of Parasitology and Animal Diseases, Veterinary Research Division, National Research Center, Dokki, Giza, Egypt. ${ }^{8}$ Estación Biológica de Doñana, Consejo Superior de Investigaciones Científicas (CSIC), Avda.

Américo Vespucio s/n 41092, Sevilla, Spain.
\end{abstract}

Published online: 07 December 2015

\section{Reference}

1. Angelone-Alasaad S, Molinar Min A, Pasquetti M, Alagaili AN, D'Amelio S, Berrilli F, et al. Universal conventional and real-time PCR diagnosis tools for Sarcoptes scabiei. Parasit Vectors. 2015;8:587.

\footnotetext{
* Correspondence: sameralasaad@hotmail.com; luca.rossi@unito.it

'Dipartimento di Scienze Veterinarie, Largo Paolo Braccini 2, 10095

Grugliasco, Italy

Full list of author information is available at the end of the article
}

Submit your next manuscript to BioMed Central and take full advantage of:

- Convenient online submission

- Thorough peer review

- No space constraints or color figure charges

- Immediate publication on acceptance

- Inclusion in PubMed, CAS, Scopus and Google Scholar

- Research which is freely available for redistribution 